\title{
A Korean Painter under Japanese Colonization and His European Experience: Pai Un-soung, between the East and the West
}

\author{
Shin Min-Jong \\ Department of Comparative Literature and Culture, Interdisciplinary Cultural Studies, \\ Graduate School of Art and Sciences, the University of Tokyo, Japan
}

Copyright $\subset 2017$ by authors, all rights reserved. Authors agree that this article remains permanently open access under the terms of the Creative Commons Attribution License 4.0 International License

\begin{abstract}
This paper aims to present a more flexible approach toward the Korean modern art, by exploring the work and art of a Korean modern artist Pai Un-soung (1900-1978) in Europe from multiple perspectives. Because the modernization of Korean art includes the Japanese colonial period (1910-1945), Korean modern art has been negatively recognized as a "passive" one and an "epigone" of western art "distorted" by Japan. Under those circumstances, Pai was the first Korean modern painter who studied "original" Western painting in Europe, rather than in Japan. Not only that, he was the only one who worked in Europe for 18 long years with accomplishments far too numerous to count. Pai's various activities conducted in Europe suggest the active and international aspects of Korean modern art. In this paper, I will focus on the Pai's stay in Europe and examine his activities and artworks, in connection with the political, social, and cultural situation of European society in the 1920s and 1930s. Through this paper, I hope to not only present a transnational viewpoint on Korean modern art, but make a request for mutual understanding and a spirit of cooperation in the study of art history between the East and the West.
\end{abstract}

Keywords Korean Modern Art, Japanese Colonization, Modernism, Study Abroad, Koreanness

\section{Introduction: Korean Modern Art and Europe}

What is Korean modern art, and when did it begin? In general, the modernity of Korean art includes the period that Korea was under Japanese colonial rule (1910-1945). Therefore, it is ironically said that the modernization of
Korean art was born and developed under the domination and governance of Japan, the Other. ${ }^{1}$ At any rate, it is true that Koreans came to experience modernity in this period. Exhibitions were held, new art systems were implemented, and Western oil painting was introduced for the first time to Korea. Art education is particularly noteworthy. Despite Korea encountering the very new mode of Western art and wanting to learn it, professional institutions for art education had never existed. ${ }^{2}$ For this reason, people who wanted to study Western art had gone abroad. What is interesting is that most people studied Western art in Japan and acquired knowledge from Japanese books rather than books from the West. Realistically considering their economic and cultural possibilities, they took the opportunity to study art in Japan, the country that had adopted Western culture before Korea and had been acting as a bridge to Western civilization. In this way, the major features of Korean modern art, especially Western-style art were imported "via Japan," not directly from the West. Because of this historical situation, there have been many arguments surrounding the modernism of Korean art. For instance, some point out that Korean modern art is nothing but (and no more than) Western-style painting that was "distorted" and "interpreted" by Japan. Some criticize Korean art for being only an "imitation of Western art."

Under those circumstances, the importance of Korean painters who studied art directly in Europe was emphasized. The expectations of the artists who had experienced the "birthplace" of oil painting and mastered "original" Western painting seemed immense. It is generally known that five

\footnotetext{
1 Japan had emphasized the "backwardness" of Korea, implementing their "modernized (Westernized)" art systems. They also maintained that Korean art could be modernized, courtesy of Japanese colonial rule. [Kim Young-Na, Kanbayashi Tsunemichi (translation), 20th Century Korean Art, Tokyo, Sangensya Publishers Inc. 2011. p. 19].

2 Art institutions had never been founded in Korea during Japanese colonization. As a result, the art education of this period was exclusively conducted at private art studios, run by individual artists or small art groups. [Kim Young-Na, Kanbayashi Tsunemichi (translation), ibid. p. 20].
} 
Korean painters had studied in European countries before the Second World War. ${ }^{3}$ However, not only the number is extremely small compared to the number of artists who studied in Japan, ${ }^{4}$ but most of their stays were also short and did not exceed three years. It would have never been easy for Korean to perform brilliant exploits in the European art world, and it is hard to grasp their experiences or careers during their stay in Europe, as related data have not been fully discovered. Similarly, it is not easy to evaluate or study the Korean artists who had been in Europe despite their significance. ${ }^{5}$

This is why Pai Un-Soung (1900-1978) is worthy of notice. Pai is not only the first Korean painter who studied art in Europe, but he is also the only one who worked in Europe for 18 long years (1922-1940). Consequently, materials that show Pai's activities are still available to research. Moreover, Pai's achievements in Europe, including his award-winning career and private exhibitions [Tab. 1], and his paintings, which were owned by European museums [Tab. 2], suggest the active and international aspects of Korean modern art (or Colonial Art), which have only been passively recognized to date. Not only that, but as the culture and art Pai experienced in Europe was fundamentally different from that of Japan (and what other Korean artists experienced in Japan), inquiring into Pai suggests another aspect of the movement or cultural exchange of Korean art during the modern period.

This paper will focus on Pai's artistic activities and his artworks during his stay in Europe. To be more specific, this paper examines Pai's paintings produced in Europe and his work undertaken in the same place (Germany: 1922-1937, France: 1937-1940), in connection with the political, social, and cultural situation of European society in the 1920s and 1930s. I will look at this problem multilaterally, at the public and the private level as well. By doing so, I will clarify the importance of Pai's art in Korean modern art history. Through this paper, I hope to not only present a transnational viewpoint on Korean modern art, but make a request for mutual understanding and a spirit of cooperation in the study of art history between the East and the West.

3 The names of the painters were: Na Hyei-Suk (1896-1948), Lee Jong-Woo (1899-1981), Pai Un-Soung (1900-1978), Yim Phah (1901-?), Paik Nam-Soon (1904-1994).

4 The number of Korean students who studied art in Japan is far more than the number who studied in Europe, which included 62 students at the Tokyo School of Fine Arts (Tokyo Bijutsu Gakko), 147 students at the Japanese Imperial Art School (Teikoku Bijutsu Gakko), 104 students at the Women's Art School (Joshi Bijutsu Gakko), etc. [Yoshida Chizuko, Study on East Asian Art Students in Modern Period: Historical Records on International Students of Tokyo School of Fine Arts, Tokyo, Yumani Shobou, 2009, pp. 133-139].

5 There are several monographs about Korean modern artists who studied in Europe: Lee Gyeong-Mo, Study on the Painters Who Studied Western Paintings in Europe in 1920-30s, Problems in the Arts of East and West, vol.4, Seoul, Institute of Contemporary Art of Kyunghee University, 2002, pp. 87-120; Lee Ji-Hee, Study on Korean Artists Who Studied in Paris in the 1920s and 1930s, Biography of Artists, vol.8, Society of Biography of Artists, 2012.12, pp. 179-218; Yun Beom-Mo, Formation of Modern Women's Art: In the Case of Na Hei-Suk and Paik Nam-Soon, Na Hei-suk Study, vol.2, 2013.6, pp. 167-191; Kim Mi-Geum, Study on Pai Un-Soung's Paintings During His Years in Europe, 1922-1940, Journal of Korean Modern and Contemporary Art History, vol.14, Seoul, Association of Korean Modern \& Contemporary Art History, 2005.8, pp. 125-167.

\section{Pai Un-Soung in Europe and His "Koreanness"}

The epithet "first Korean painter who studied in Europe" has played a role in highlighting Pai's importance in Korean modern art history. However, beyond the context of Korea, his art, life, and identity are remarkable from a world history perspective as well. It is because Pai's life, his dual nationality as a Korean in a Japanese colony, and the places he had experienced like colonized Korea and Europe, involve various aspects of complicated world history. More specifically, Pai witnessed his country becoming a Japanese colony in 1910, at the age of ten. During his stay in Berlin from 1922 to 1937, he experienced the incompatible social and cultural milieu of both the Weimar Republic and the Nazi regime. When Paris was occupied by German forces in 1940, Pai returned to Korea after his three-year sojourn in Paris from 1937 to 1940. In Korea, he is said to have cooperated with Japanese imperialism, which had entered "a state of war," by pledging fidelity to "paint in service of the country 絵画奉公” and “paint for the state 画筆報国." Despite such a brief description, it is not hard to understand that Pai's life involved working in various places, and developed in diverse historical and social situations to which numerous ideologies were intricately connected.

It is remarkable that Pai starts studying in Japan in the same year of his participation in the March First Movement (also known as Sam-il Movement), resisting against the Japanese colonial rule in $1919 .{ }^{6}$ In addition, he decides to go to Europe in 1922, three years after his study in Japan. It seems likely that demands for nationalism and his desire for modernism were being pursued, simultaneously, in parallel. The reason Pai decided to be a painter might have been the admiration for "visual modernity" he identified in Western painting. ${ }^{7}$ From 1925 to 1930 , Pai studied Western art at the Unified State Schools for Fine and Applied Arts (Vereinigte Staatsschulen für freie und angewandte Kunst), receiving instruction from a German artist Ferdinand Spiegel. The 1920s were a "golden age" for avant-garde art in Berlin. In an atmosphere of freedom and enterprising spirit, liberal artists such as Karl Hofer, ${ }^{8}$ woodcut artist Käthe Kollitz

6 Records on Pai's participation in Korean independence movements may be summarized as follows: Cooperation with Jeong Pil-Seong of Daedongdan, Maeil Shinbo, 1919.11.30; Lee Jae-Hyun, Handbook of Chosun Contemporary Artists, Pyongyang, Literary Arts Publishing Company, 1999, pp. 234-237.

7 It is said that Pai majored in economics in Japan and he also headed to Europe to study economics. However, after arriving in Europe he changed his mind to study Western art. According to his reminiscences, Pai was inspired and moved by the paintings of Leonardo da Vinci, which were the first oil paintings he saw in Europe. He says this experience aroused his instinct and aspirations concerning art. [Pai Un-soung, Dumb Artist and Château de Bruneaux, Munhwa Ilbo, 1947.3.19].

8 Karl Hofer (1878-1955) was a German expressionist painter. He was renowned for the expression of figures that seemed like sculpture, with boldly divided and contrasting color surfaces. He primarily described the mood of melancholy or pessimism in modern life. He served in the Unified State Schools for Fine and Applied Art in 1921, but from the late 1920s, his work was suppressed for having criticizing Hitler's cultural policy and he was branded as a degenerate artist. [Kim Mi-Geum, ibid. pp. 8-16]. 
(1867-1945), and stage artist Oskar Schlemmer (1888-1943) served as teachers at this school, and there were plenty of opportunities for students to acquire knowledge of various forms of contemporary art in real time. Nevertheless, Pai seems to have been indifferent to these kinds of experimental arts, and always retained his love of classicism. He is thought to have regarded the sound techniques of classicism as the ideal. Otherwise, it could have been the influence of his teacher, Spiegel, who painted classical styled works throughout his lifetime. ${ }^{9}$

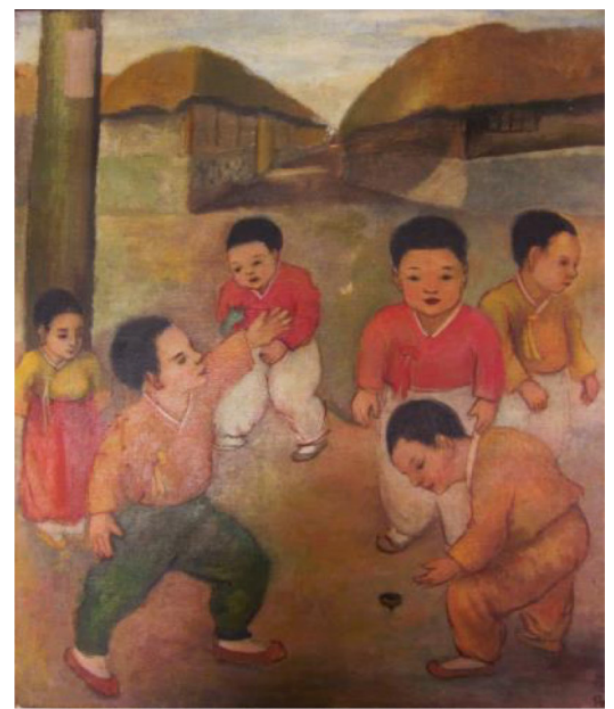

Figure 1. Pai Un-soung, Children spinning a top, 1930s, oil on canvas, $55 \times 45 \mathrm{~cm}$, Ethnological Museum, Berlin, Germany.

After his graduation in 1930, he began to work as a professional artist in Berlin, and chose as his artistic identity "Korea." He expressed "Koreanness" in various ways. He reproduced old Korean customs in his paintings [Fig. 1], painted in Indian ink on special papers[1], and drew pictures on woodcut with Chinese brushstrokes.[2] It is of particular interest that Pai had drawn his subject matter from his national identity and characterized this Koreanness as the defining feature of his art, although he had received an education in Western art. It seems that this was Pai's realistic response to the European society of that time where an interest in Asian art had been increasing.

In comparison with the Chinoiserie of the $17^{\text {th }}$ and $18^{\text {th }}$ centuries or the Japonisme of the $19^{\text {th }}$ century, which had primarily focused on stylistic acceptance, European society was taking it one step further at the beginning of the $20^{\text {th }}$ century and was conducting academic and specialized study on Asian culture at this time. ${ }^{10}$ However, this interest

9 Ferdinand Spiegel (1879-1950) was an artist who painted in a conservative style. Thematically, he preferred to draw rural life, farmers, and battle scenes. His paintings were welcomed by the Nazi regime as his materials justified German militarism. [Kim Mi-geum, ibid. pp. 8-16].

10 For example, "German Oriental Society Deutsche Morgenländische Gesellschaft" was one of the largest research organization dedicated to studies of Asia. [Germain Bazin, The Museum Age, New York University Books, 1967, pp.193-238. Cited in Kim Mi-Geum, ibid., p. 90]. applied only to some countries, such as China and Japan. Korean culture was still seen as uncivilized and folkloric. ${ }^{11}$ For example, the "East Asian Art Association (Die Gesellschaft für die ostasiatische Kunst)," a research organization of East Asian art founded in Berlin in 1926, held a regular workshop for the purpose of understanding East Asian art. Among the total of 109 workshops held from 1926 to 1944, research on Korean art was conducted only three times, compared to 45 studies on China and 23 on Japan.[3] This indicates that Europeans in those days appreciated a very rigid hierarchy of East Asian culture. German anthropologist Adolf Bastian (1826-1905) classified non-European cultures into "primitive" and "highly developed," and Danish ethnologist Kristian Bahnson (1855-1897) insisted that East Asian Collections in the ethnological museums in Europe should exhibit "the culture of civilized people," which should be separated from those of "primitive peoples." Unfortunately, the term East Asia referred only to Japan and China. Korea was not included. [4]

In this social atmosphere, Pai established his identity as an "Asian artist in Europe" and he must have believed this identity could guarantee his artistic originality. Even if Korean art was less a concern than that of China or Japan, the Korean culture as expressed in Pai's art fascinated European people as exotic Asian images. It may be said that he preferred self-orientalism or self-exoticism to describe "Korean people's indigenous ethnic life" [5] and to consolidate his position as artist in that way. In addition, he intended to introduce Korean customs and traditions to European with his painting. ${ }^{12}$ He tried to show the culture and the aesthetic sense of Korea through his art in European society where the understanding of Korea was still insufficient. Pai's Self-portrait, wearing a hat [Fig. 2] shows these circumstances and his self-awareness in an indirect way. In the painting, Pai is wearing a costume that seems like a mixture of the garments of Korean shaman, king, and military officer. Behind him, a typical bar or dance hall of the Weimar Republic is painted as his background.[6] This kind of composition reflects Pai's self-recognition of a "Korean in Europe." He strongly expressed his identity as a Korean (more than as an artist) by representing himself in Korean traditional costumes. Moreover, he might have had an

11 The Korean collection in European countries, which was formed during the end of the $19^{\text {th }}$ and the beginning of the $20^{\text {th }}$ century, consists of objects gathered by individual travelers. They collected these according to their personal preferences and chose things easy to carry rather than things of a high artistic value. For these reasons, some of the Korean objects were from an unknown source. Most Korean collections in Germany are composed of objects such as celadon ceramics, adornments, and items of daily_use. [Korea Rediscovered! Treasures from German Museum, Catalogue, The Korea Foundation, 2011, pp. 10-11].

12 Kurt Runge, a friend of Pai during his stay in Germany, says that Pai recognized Korea had been little known in Europe and decided to show his motherland's beautiful culture to Europeans. Pai tried to introduce Korea in various ways such as through painting Korean customs or writing articles on Korea, singing Korean songs, and telling Korean fairy stories. [Kurt Runge, Pai Un-soung, Telling About His Hometown, Kulturbuch Verlag, Darmstadt, 1950; Kim Bok-Ki, Pai Un-soung, Life and Work of the First Korean Artist Who Studied in Europe, Monthly Art, 1991.4, p. 52]. 
educational intent to display Korean ethnic costumes, which were some of the main objects of the Korean collection in European museums. ${ }^{13}$

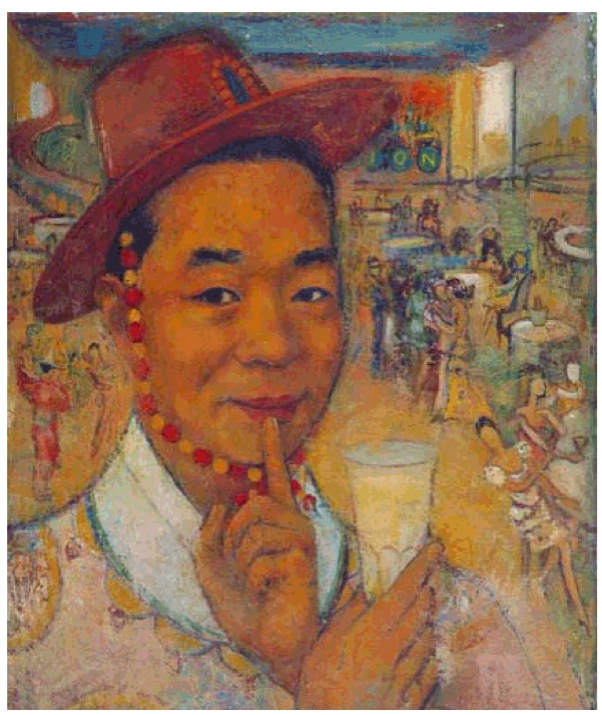

Figure 2. Pai Un-soung, Self-portrait wearing a hat, 1930s, oil on canvas, $45 \times 54 \mathrm{~cm}$, Private collection.

Meanwhile, the composition of Pai's image through dressing in Korean traditional Hanbok, taking a champagne glass in his hand, and standing in a European café seems heterogeneous. This paradoxical scene has connotations of the antithetical values of "the East and the West" or "tradition and modernity." Furthermore, it causes a sense of tension and deepens the visual interest at the same time. Art of this type by Pai was highly appreciated as "an intriguing fusion art of Asian and European painting concept" [7] and it attracted Europeans. Pai had tried to harmonize or contrast the East and the West in his art in various stages, including through subject matter and techniques. This "coexistence" of conflicting values through the art was the most fundamental principle of Pai's art.

\section{Dreaming the Harmony of Eastern and Western Art: Painting "Eastern Lines and Western Colors 東線西色”}

As his appearances in self-portraits had already shown, capturing artistic elements of the East and the West harmoniously, and presenting rhythm and dynamics to his paintings were at the very core of Pai's art. "Eastern Lines and Western Colors," which means "Materials brought from the East, Techniques and Colors from the West" [8] is the expression that best describes the qualities of his art. This characteristic seems similar to the Korean aesthetic "grafting 接和," which implies “Opposing concepts get fused and become one."[9] The following interview illustrates Pai's stance, which recognizes the value of both East and West equally, and encourages acknowledgment of the importance of Oriental classics: "In order to make Western painting completely our own, it is not enough with the Western classics. I believe that when it comes to the essence of painting, both the East and the West have something invaluable. If so, I don't think one should forget about the Eastern classics simply because one wants to do Western painting."[10] For Pai, the supreme goal to accomplish in Europe was to reconcile the beauty from both, making the best of their individual traits. He must have felt dedicated to create "Korean-styled oil painting" with the Western techniques he had learned. At the same time, he is thought to have felt responsible for introducing Korean culture to Europeans for whom it was still strange. Self-portrait, wearing a hat is also the painting which complies with the logic of "Eastern Lines and Western Colors." We can identify the combination of Eastern materials of Korean ethnic traditions and Western techniques of oil painting, with the combination of Asian characters and European background as well. His turns of expression, use of intense colors, and free and relentless use of brushwork in particular are reminiscent of French Fauvist painter Raoul Dufy; in Pai's art they seem experimental and exceptional examples. These kinds of expressions were regarded as his "mastery of avant-garde styles" by a German art historian. [11]

\subsection{Oriental Materials and Color Aesthetics: Returning Home}

Returning Home [Fig. 3] is an oil painting produced in 1938. As a typical "Eastern Lines and Western Colors" painting, it was submitted for the Autumn Fair and Le Salon in France [Tab. 1]. It appeared in the catalog of Le Salon 1938 as well. The subject matter of a man slogging his way through the snow is thought to have originated in the theme of Looking for Plum on the Bà Bridge 灞橋尋梅図, called Scouring about Plum Blossom as well. This theme, which means "In early spring, I cross the Bà Bridge on a donkey and go into the mountains covered with snow in order to find plum blossoms" ${ }^{14}$ is derived from an ancient event by a Chinese poet of the Tang period, Meng Haoran (689-740). Many Korean painters of the Joseon Dynasty era (13921897), including Shin Jam (1491-1554), Shim Sa-Jeong (1707- 1769), and Jeong Sun (1676-1759) drew this subject [Fig. 4], with the purpose of representing the elegant and 
unworldly spirit of a Confucian scholar. Similarities in theme and composition are found in Ishiyakushi [Fig. 5], the forty-fifth work of The Fifty-Three Post-Stations along the Tokaido Highway 東海道 五十三次之内, an Ukiyo-e woodcut series by Utagawa Hiroshige ${ }^{15}$ as well. The Fifty-Three Post-Stations along the Tokaido Highway was a series of landmark Ukiyo-e woodcuts describing sights of the 53 stations located on the Tokaido highway (the road connecting Edo (Tokyo) and Kyoto), and this series was produced in the first half of the 1800s. It is well known that the excellent Ukiyo-e collection in Europe animated Pai on his study of woodcut expressions. ${ }^{16}$ It seems that Ukiyo-e may have inspired him even for materials.

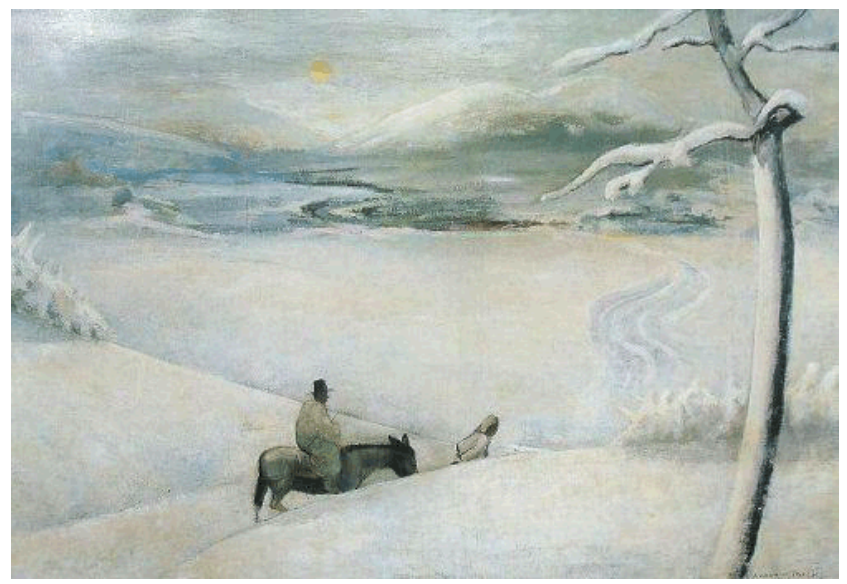

Figure 3. Pai Un-soung, On the Way Home, 1938, Oil on Canvas, $110 \times 160 \mathrm{~cm}$, Private collection, Korea.

White snow covering the whole screen is important as it conveys the Oriental emotion. A landscape of snow is also one of main theme of Western art. For example, French impressionists such as Claude Monet and Camille Pissarro painted white snow in order to express the change of colors with reflection of light. On the other hand, Pai seems to have painted the snowy landscape to describe a still and calm atmosphere of Asia, rather than grasping technically the beauty of color or the flow of air. Pai's expression of sunset in the evening, the village faintly visible in the distance, walking toward the village as it appears from the back, and the footprints in the snow of those who have already passed that way evoke lonesomeness and quietude. These

15 Utagawa Hiroshige (1797-1858) is one of the most prominent Japanese Ukiyo-e woodcut artists in the Edo period and is especially famous for his landscape woodcut print. Many museums throughout the world, including the Metropolitan Museum of Art, the Museum of Fine Arts in Boston, and the Musée National des Arts Asiatiques Guimet possess wonderful collections of Hiroshige. In the case of Germany, many monographs on Ukiyo-e woodcut, such as The Japanese Woodcuts: With Eighty-Eight Illustrations and Three Signature Panels (München, R. Piper, 1911) or From Moronobu to Hiroshige: Masterpieces of Japanese Woodcut Selected, Initiated and Described by Julius Kurth (Berlin, Josef Altmann, 1924) were written by Julius Kurth in the early $20^{\text {th }}$ century. These studies enhanced German understanding of Ukiyo-e art.

16 Pai is known to have studied Ukiyo-e for about one year to develop his original woodcut expression. [U.T. Unsoung Pai, Hamburger Anzeiger, Nr.69 (Marz 22, 1935)]. expressions show a familiarity with the idea that white symbolizes "the beauty of sorrow" in Korea[12], indicated by an eminent Japanese aesthetician and philosopher Yanagi Muneyoshi (1889-1961). On the other hand, Nakahara Yusuke, a Japanese art critic pointed out that:

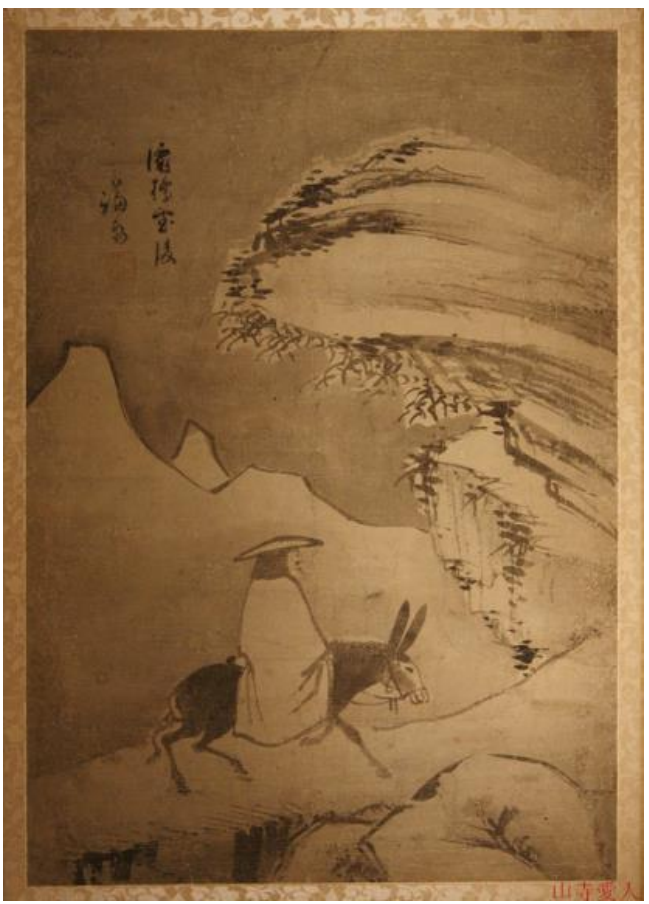

Figure 4. Jeong Seon, Crossing the Bà Bridge covered with snow, $18^{\text {th }}$ century, Ink on Paper, $53 \times 36 \mathrm{~cm}$, National Museum of Korea, Seoul, Korea.

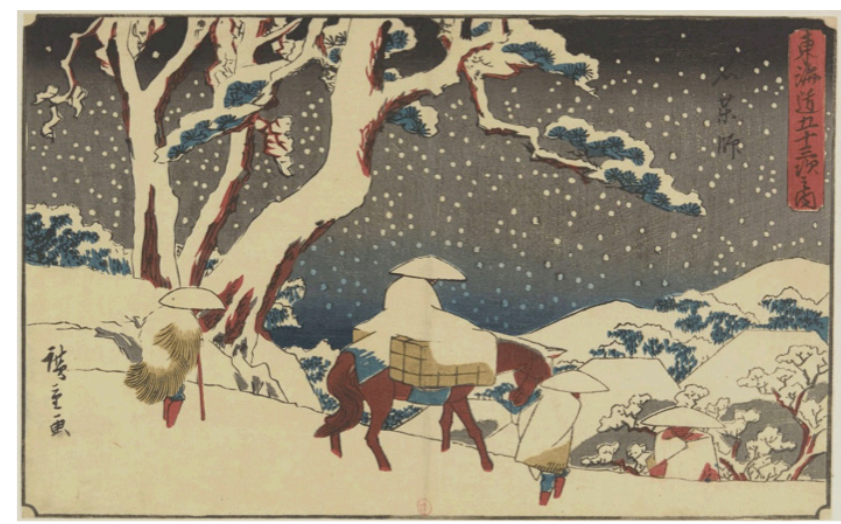

Figure 5. Utagawa Hiroshige, The Fifty-Three Post-Stations along the Tokaido Highway: [45] Ishiyakushi, 1841-1842, Ukiyo-e woodcut, $19.8 \mathrm{x}$ $31.6 \mathrm{~cm}$.

Korean artists seem to deny use of a variety of colors. This negation of colors (= preference of achromatic colors: author's note) $[. .$.$] indicates that they express interests in$ something other than colors. [13] 


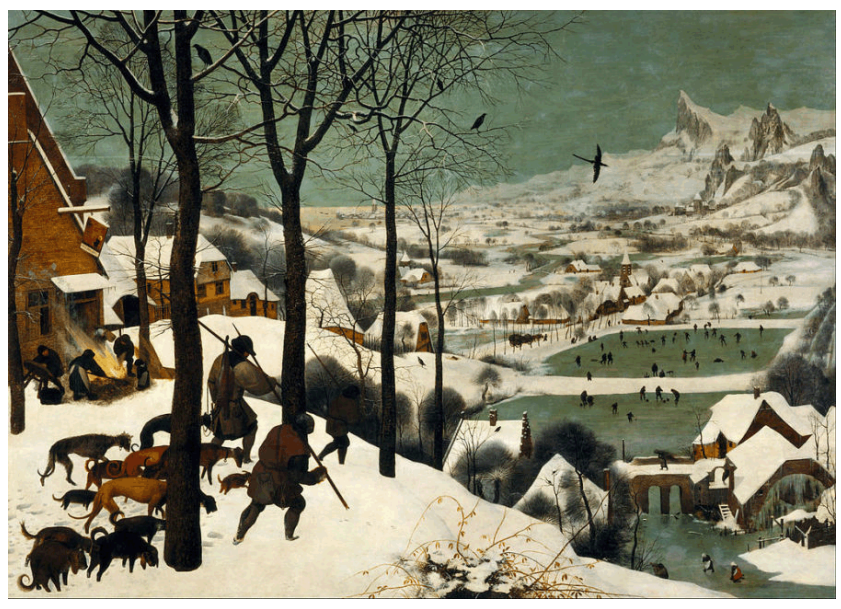

Figure 6. Pieter Bruegel the Elder, The Hunters in the Snow, 1565. Oil on Canvas, $117 \times 162 \mathrm{~cm}$, Kunsthistorisches Museum, Vienna, Austria.

As this comment shows, Pai places value on the impression of space and emotional expression over the color white itself. The space in Pai's painting includes meditations and expresses the Oriental aesthetics referred to as "fullness coming from emptiness." For example, there are parallels between Hunter in the Snow [Fig. 6] by Pieter Brueghel and Pai's Returning Home, such as expressions of snowy scenes or views from above. ${ }^{17}$ However, Brueghel weaves a narrative by drawing many subjects into the screen, whereas Pai's painting is not overly finished and still appears quite open. Two paintings show a definite difference between the Western and Eastern aesthetic of "Being" and "Nothingness." Returning Home demonstrates Asian sentiment with all of the subject matter, simple and flat composition, and color and line drawing. These expressions were highly appreciated by a French critic as "(Pai) instilled life into his painting with his light matière and vigorous line drawing." $[14]$

\subsection{Reinterpretation of a Western Theme: the Virgin in Hanbok}

Pai not only drew Korean customs with Western techniques, he painted Western subject matter in the manner of Korea. Korean Madonna [Fig. 7] is the painting where he attempted to reinterpret the image of the Virgin and Child, one of the most important themes of Western art. Pai produced this work in both oil on panel and mosaic tiles, although only the mosaic version currently remains. ${ }^{18}$ According to the relevant record, the oil painting version was produced between 1937 and 1940, at the request of priest Youn Eul-Su, one of Pai's friends in France. Afterwards, this oil painting was re-created into mosaics by an Italian artist in 1940. ${ }^{19}$ The image of the Virgin and Child hardly appeared

17 Kim Mi-Geum, ibid. p. 81

18 Mosaic version of Korean Madonna is now possessed in 'Priest Youn Eul-Sou Lawrence's Relics Exhibition Hall' of Blessed Sacrament Sisters of Charity, Abbey in Yongin-si of Korea. [Blessed Sacrament Sisters of Charity in Korea Home Page: http://www.inbo.or.kr].

19 Kim Mi-Geum, ibid., p.61; Sister Shin Jeong-Suk, Cultural Pilgrimage before 1945, and the Korean Madonna is probably Korea's first Virgin and Child painting. ${ }^{20}$ For that reason, Pai is thought to have referred to various Virgin and Child paintings in Europe when he produced Korean Madonna. For example, the close pose of mother and child, their eye contact, and the close bond of affection between them remind us of the Madonna and Child image painted by Sandro Botticelli [Fig. 8] or Leonardo da Vinci. Not only that, its background, including peaks rising into the sky, the river flowing to the rear, and the expression of depth are typical expressions appearing in the religious paintings and portraits of Renaissance and Flanders artists. Pai seems to have been inspired by these more than by any other examples.

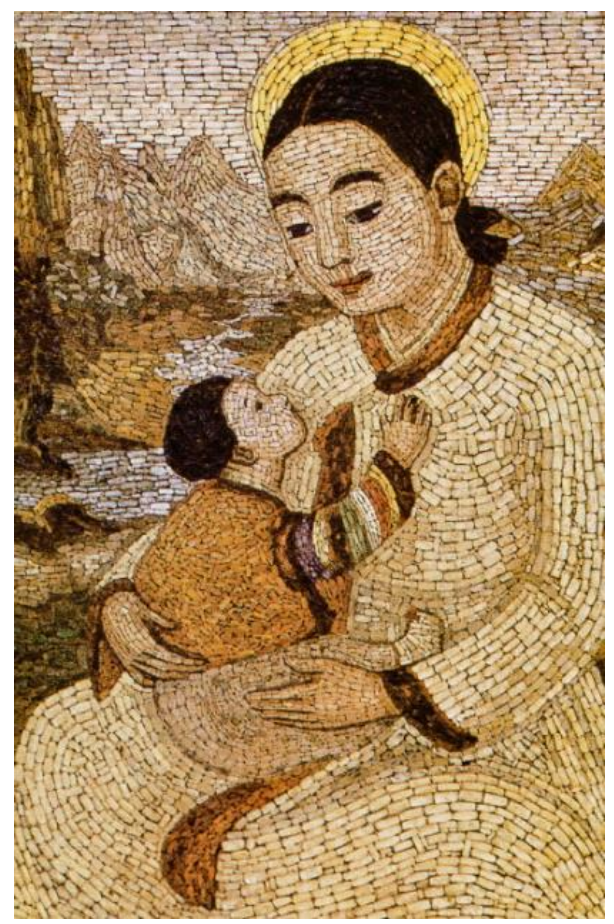

Figure 7. Pai Un-Soung, Korean Madonna, 1937-40, Mosaic, $16.6 \times 23.1 \mathrm{~cm}$, Youn Eul-Su's Relics Exhibition Hall, Blessed Sacrament Sisters of Charity, Jeonju, Korea.

The most peculiar feature of Korean Madonna is the "Koreanness" appearing in this painting. The nationality and ethnicity of St. Mary and the Child Jesus are changed and they wear Korean traditional Hanbok. In the background is Mt. Geumgang, a representative mountain of Korea. ${ }^{21}$ The Virgin is depicted as an ordinary woman who conveys a

to the Museum: Priest Youn Eul-Sou Lawrence's Relics Exhibition Hall 2, Image of good old mother, expressed as the image of Virgin and Child in a mosaic, Catholic Times, Seoul, vol. 2972. Catholic Times, 2015.12.06, p.13. 20 Sister Shin Jeong-Suk, ibid. 2015.

21 Priest Youn Eul-Su left a message on the back of the postcard on which Korean Madonna was printed. In this memo, he said: Artist Pai Un-Soung is my friend with whom I studied in Paris. He expressed the maternal love with Mt. Geumgang in the background at my request. [Lee Myung-Hee, Study of Devotional Images of the Virgin Mary of Korea in modern era, Master's Thesis, Seoul, Myongji University, 2015, p. 160]. 
"secular maternity."[15] Her son, the Christ Child, appears without a halo on his head and is spreading his arms toward his mother. There is no theological meaning in their image. In this way, Pai combined the style of Western religious material and Korean genre painting. By doing so, he re-created an exotic and humble Virgin and Child of Korea. In Korean Madonna, conflicting logics such as religious and secular, the West and the East coexist. ${ }^{22}$

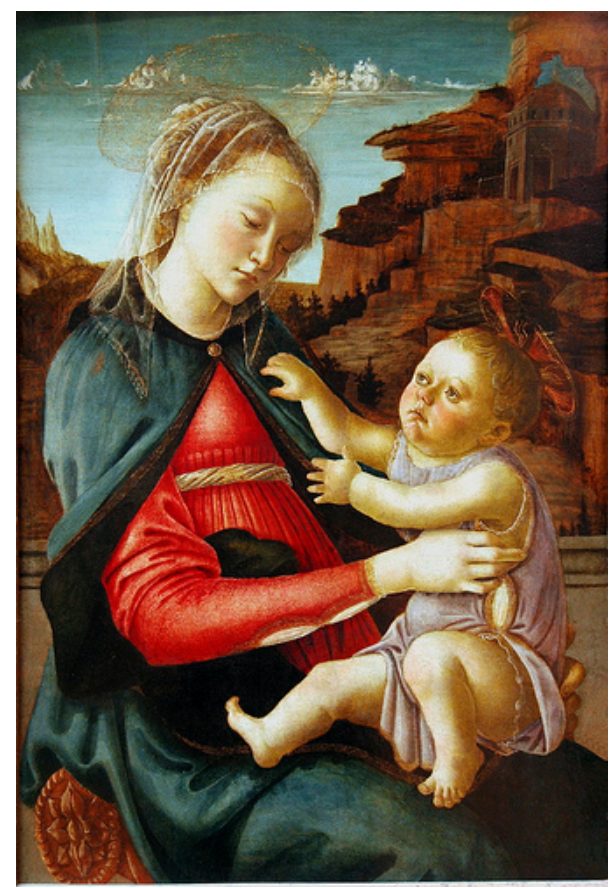

Figure 8. Sandro Botticelli, Virgin and Child, known as the Madonna of the Guidi da Faenza, around 1465, Oil and Tempera on wood Panel, $73 \times 49 \mathrm{~cm}$, Musée du Louvre, Paris, France.

In addition, Pai produced many kinds of "Eastern Lines and Western Colors" paintings such as Family Portrait or Korean Bride. ${ }^{23}$ For him, Europe was the place he recognized and, equally, accepted the opposing values of the East and the West. Moreover, he focused on a meaningful principle to harmonize these values through his art. His "Eastern Lines and Western Colors" were undertaken in a manner that respected each culture and overcame the dichotomous thinking of "Eastern spirit and Western techniques 東道西技.”

\section{Colonial Experience Outside of Korea: Pai's Activities and Influence in Japan}

\subsection{Pai's Woodcut Expressed Japan: Baron Mitsui and His Works}

Pai seized many opportunities in liberal and diverse

22 Hyung-Min Chung, ibid. pp. 88-89.

23 Korean Bride, which depicted the Korean traditional wedding ceremony, is painted as a cover illustration of the magazine Die Dame, issued on Aug. 1, 1935. cultural milieus. He worked as an illustrator of magazines, submitted works to various exhibitions, and held solo exhibitions all over the Europe [Tab. 1]. Not only that, he worked as a news reporter in Korean journalism when the Berlin Olympic was held in 1936[16], covered festivals, expositions and exhibitions held in Paris, ${ }^{24}$ and also played an extra in a movie. ${ }^{25}$ In the process, he became intimate with many European artists and influential people, and received their support. ${ }^{26}$ For example, it is known that Ewald Hoinkis, a famous German fashion photographer, introduced Pai to the German press and prominent people from various circles. Another friend, Kurt Runge, who collected Korean fairytales listened to Pai, learned of his woodcut images, and published a book titled Korean Old Stories Heard From Un-soung Pai in Berlin in 1950. ${ }^{27}$

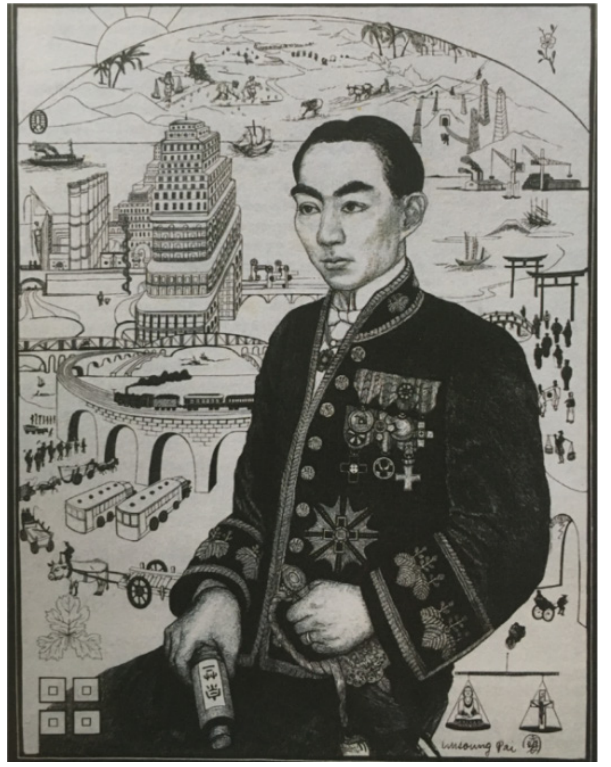

Figure 9. Pai Un-soung, Baron Mitsui and His Works, 1935, woodcut, $55 \times 43 \mathrm{~cm}$, Ethnological Museum, Hamburg, Germany.

The relationship with the Japanese is particularly worthy of attention. Pai is said to have been sponsored financially by Japan during his stay in Europe, and his woodcut Baron Mitsui and His Works [Fig. 9] is one of the clues for understanding this situation. This work was produced in 1935 at the request of Mutsui Takaharu (1900-1983). It was exhibited at his solo exhibition at the Ethnological Museum Hamburg in 1935 for the first time, and since then, it remains housed in the same museum.[17] Mitsui Takaharu, the character of this work, was an entrepreneur who had served as a director of the Mitsui Mining Company and Mitsui Corporation, and the first president of the Mitsui Shipping Company. He is also known as a figure who tried to promote cultural exchanges between Japan and European

24 Paris News: International Exhibition Scheduled to be Held Next Year, Dong-A Daily News, 1936.6.4, p.7; Paris News: Spring Art Exhibition, Dong-A Daily News, 1936.6.5, p. 7. etc.

25 Frank Hoffmann, ibid., p. 102.

26 Frank Hoffmann, ibid., pp.100-102.

27 Frank Hoffmann, ibid., pp.101-102; Kim Mi-Geum, ibid., p. 24. 
countries.[18] It is presumed that this woodcut was made to praise Mitsui's achievements in business, and especially to commemorate the fruition of the cultural exchanges with Eastern European countries. Closely drawn "accomplishments" in the background and seven medals on his uniform ${ }^{28}$ support the purposes of this production. Mitsui and His Works had a favorable notice in the press: "In this woodcut, the texture of clothing, skin, and medals are successfully expressed. It gives a new model for modern prints to follow"[19]; when it was exhibited in his solo exhibition in Hamburg and the following year of 1936, when it was submitted to the International Woodcut Print Exhibition held in Warsaw, it was awarded honors. Besides the portrait of Mitsui, Pai painted Mrs. Mitsui's portrait in oils; Mitsui took this opportunity to become a patron of Pai's in many different ways. According to Cho Taek-won, a Korean dancer and Pai's acquaintance in Paris, Pai received a large amount of money as remuneration for Mitsui's portrait and purchased an exclusive atelier in Paris. ${ }^{29}$ Not only that, Pai is said to have drawn four pictures for the Japanese embassy in Berlin, through the good offices of Mitsui. ${ }^{30}$ Almost all of the Pai's solo exhibitions held across Europe were funded by Japanese organizations and many other Japanese individuals. Pai was supported by Japan including Mitsui, both officially and unofficially. ${ }^{31}$

\subsection{Pai's Activities in Paris and Relations with Japan}

Pai's activities in Paris from 1937 to 1940 further clarify his relationship with Japan. In Paris, Pai submitted paintings to Le Salon and Autumn Fair and held his solo exhibition in 1938. In addition, he did illustrations for the magazine France-Japan and participated in the Japanese Artists' Exhibition in Paris [Tab. 1] The latter two especially deserve attention, as they have not been thoroughly discussed in previous research to date. France-Japan was the magazine published with the intention of strengthening relations between France and Japan. It was therefore referred to as "Japanese-French cultural exchange magazine" as well. The first edition was published in 1934 and a total of 49 volumes had been issued by 1940, financed by the South Manchuria Railroad Company and supported by the French-Japanese

28 It is said that Mitsui received these medals in seven Eastern European countries including Austria, Hungary, Poland and the Czech Republic for his outstanding cultural exchange services. [Matsushita Hirokichi, New Research on Zaibatsu Mitsui, Domestic and Foreign Industrial Research Committee, 1936, p. 53. Cited in Kim Mi-Geum, ibid., p. 54].

29 Pai's atelier was located in Avenue de Saxe of Paris. This was the area where celebrated artists preferred and their studios were concentrated. According to the catalogue Le Salon 1938, Pai's address was marked as 59,

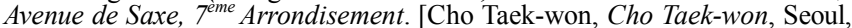
Knowledge Smith, 2015, p. 75].

30 In relation to this production, an article was published in Die Dame. I explains Pai's work as follows: "This artist is now drawing several pictures in silk for the Japanese Embassy." These paintings were completed in 1937 and were hung on the both sides of the stairs on the entrance and in the reception room. [Frank Hoffmann, Telling This Painter: Pai Un-Soung, His Footprints for 16 Years in Berlin, Monthly Art, vol. 87, 1991.4, p. 61; Frank Hoffmann, ibid., p. 97].

31 For example, the Consulate General of Japan was involved in Pai's solo exhibition held at the Ethnological Museum, Hamburg in 1935. The Japanese authorities are said to have officially sponsored all or most of Pai's solo exhibitions. [Frank Hoffmann, ibid. pp. 100-101].
Committee. Even though it appears to be a cultural magazine, it is undeniable that this magazine served as propaganda to recover Japan's public image, which was rapidly tarnished in international society by Japan's invasion of Manchuria in 1931 and withdrawal from the United Nations in 1933.

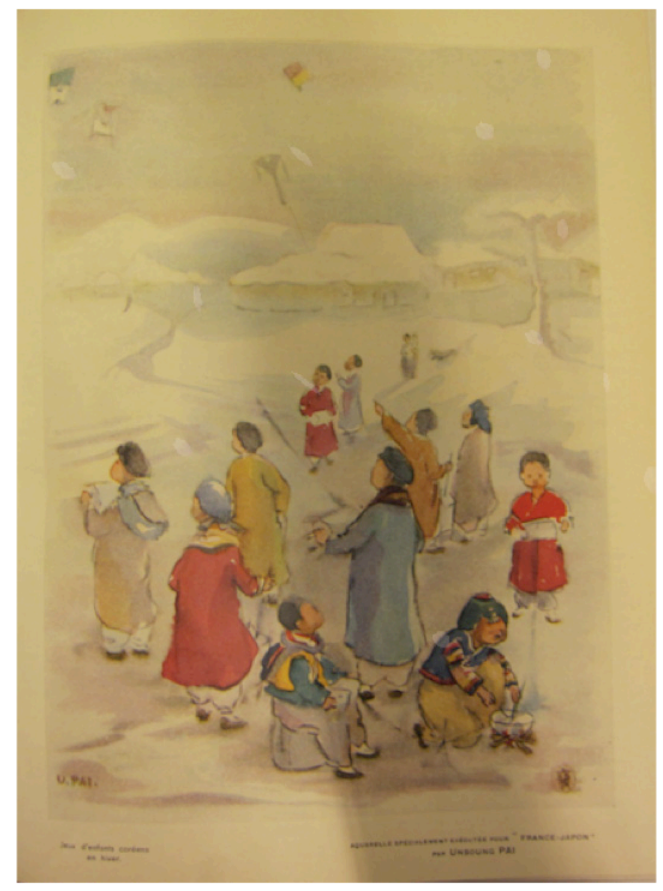

Figure 10. Pai Un-soung, Winter Game of Children in Korea, around 1938-1939, Watercolor.

Pai illustrated five paintings for this journal [Tab. 3]; the last one in particular was printed in color and formed a frontispiece to the $37^{\text {th }}$ issue (Jan. 1939) [Fig. 10]. A short text introducing the artist of this frontispiece was included in the same issue together. ${ }^{32}$ Pai was the only Korean who painted illustrations for this journal; at the same time, he was almost the only Korean artist about whom articles were written. ${ }^{33}$ The first article on him appears three months before his solo exhibition in Paris, ${ }^{34}$ and another article on his private exhibition appears once more in June. ${ }^{35}$ This seems probably to have been the first work of Pai in Paris and was conducted via multiple and intimate connections with the Japanese authorities. For instance, the French-Japanese Committee, the publisher of France-Japan, acted as a patron of Pai's one-man show. It also appears that the Japanese Ambassador to France, Sugimura Yotaro, was present at

32 The title of the illustration was Winter Games of Korean Children and it was painted in watercolors. On page 26 of the same issue, an article on Pai titled "A Special Illustration of France-Japan" was put together. In this text, Pai was described as a very unique and talented East-Asian painter, as well as one of the top-class artists of the same generation. [France-Japan, vol.37, 1939.1.15, p. 26]

33 An article on Choi Seung-hee (called Sai Sho-Ki in Japanese phonetic sign as well), a Korean dancer with an international reputation, was reported in this journal in addition to Pai. [P.N., Korean dancer Sai Shoki, (Sai Shoki, danseuse de Corée), France-Japan, vol.38, 1939.2.15, p.94]

34 Pai's solo exhibition was held from June 11 to 231938 , at the Charpentier Gallery in Paris.

35 The title of this article was 'An exhibition of Mr. Un-Soung Pai in Paris', France-Japan, Paris, French-Japanese Committee of Tokyo, 1938.6.15, p. 274 . 
Pai's exhibition [Fig. 11]. Sugimura was well known for having made an effort to promote cultural exchanges between Japan and France and had been closely linked to France-Japan as well. Pai's private exhibition is presumed to have been held as part of Japan's cultural activities and their mutual relationship.

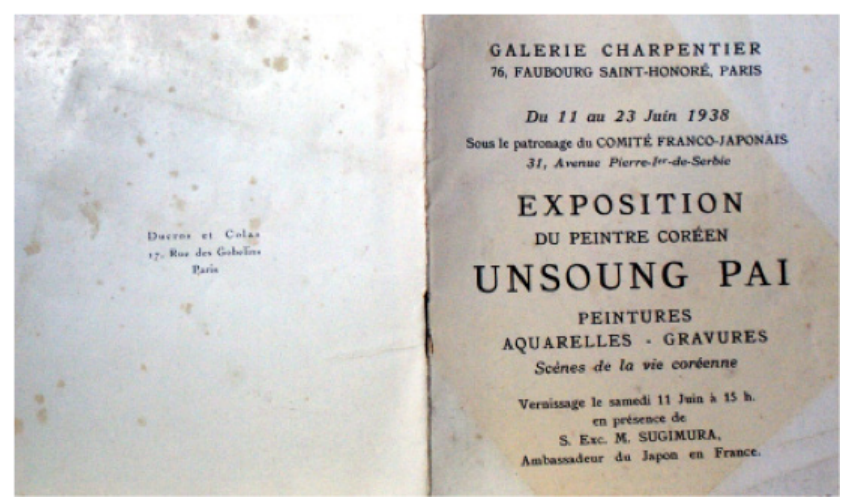

Figure 11. Invitation card of Pai Un-soung's solo exhibition

Pai's participation in the "Japanese Artists' Exhibition in Paris" cannot be overlooked either. This exhibition was designed and supported by Japanese Ambassador Sugimura Yotaro, and the Minister of Education, Jean Jay, to provide an opportunity for Japanese artists to regularly exhibit their paintings. It was held once a year both in 1938 and 1939, and many celebrated Japanese painters of the era, such as Fujita Tsuguharu and Okamoto Taro took part. ${ }^{36}$ Pai is known to have submitted his oil painting and engraving to the first exhibition and oil painting alone to the second. He also served as a member of the display along with a printmaker, Hasegawa Kiyoshi, in the first.[20] Even though specific information concerning Pai's activities in this exhibition is still not known, his name is found in the entry of the article titled "Japanese Artists' Exhibition in Paris."[21] Moreover, it is confirmed through several Japanese and French media that he submitted a woodcut print World Tour [Fig. 12] to the first exhibition held and an oil painting titled Voltre to the second.[22] As discussed previously, cultural and artistic events sponsored by Japanese authorities comprised a large proportion of his work in Paris. It seems true that Pai was able to hold a solo exhibition at one of the most prestigious galleries in Paris, even in the short period of less than one year, by virtue of support from Japanese organizations, such as the Japanese-French Committee and cooperation with

36 The first exhibition was held from December 17 to 30,1938 at the Bernheim-Jeune gallery and the second exhibition was held from June 27 to July 13, 1939 at the Charpentier gallery in Paris. Some Japanese articles in this exhibition were published at that time. The list of the articles may be summarized as follows: Onaga Hiroyoshi, Detailed Report on the Japanese Artists' Exhibition in Paris; The First Japanese Artists' Exhibition in Paris; Reviews on the First Japanese Artists' Exhibition of Paris (Articles which appeared in French newspapers), Binokuni (Country of Beauty) vol. 15 Issue 3, Binokunisya, 1939.3, pp. 53-59; The First Japanese Artists' Exhibition in Paris, Atelier, vol. 16, issue 3, Tokyo, Atelier, 1939.3.1, pp 42-43; The First Japanese Artists' Exhibition in Paris, Art, vol.14 issue 3, Tokyo, Art Publication, 1939.3, pp. 46-47.; The Second Japanese Artists Exhibition in Paris, Binokuni (Country of Beauty) vol. 15. Issue 8 , Binokunisya, 1939.8.1, pp. 28-29. them. This may seem contradictory because he is said to have always criticized Japanese imperialism and colonialism. ${ }^{37}$ For Pai, it must have been the most realistic and necessary way to receive Japanese assistance and funds, in order to work in a stable environment in Europe. As mentioned above, modernism and resistance to Japanese rule had been developing at the same time in Korea. Therefore, two emotions are found simultaneously in young Korean artists' activities: desire for acceptance of a new form of art, and hostility toward Japan. This is a result of the special historical situation in Korea, referred to as "Colonial Modernity." Pai's life also shows ceaseless ideological wanderings and uncertainties. They involve not only inner conflicts or Pai's shifting loyalties but a time period when various ideologies were in conflict, splitting and colliding.

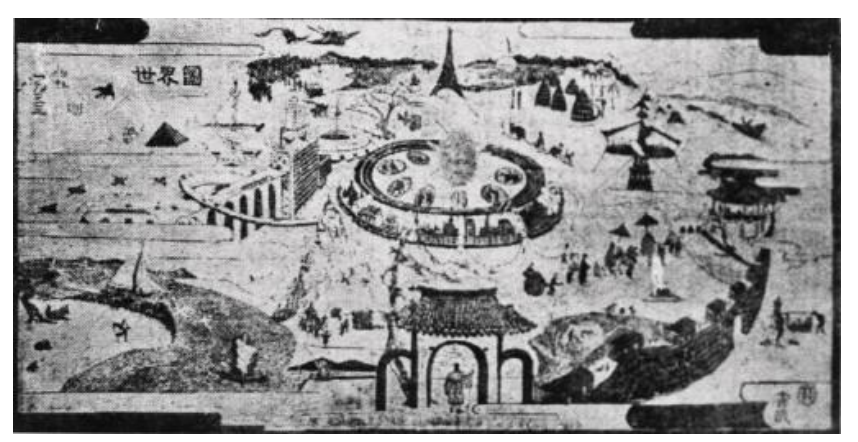

Figure 12. Pai Un-soung, World Tour (Photo of Image), 1933, woodcut, $21 \times 41 \mathrm{~cm}$, Hrubý Rohozec Chateau Collection, Hrubý Rohozec, the Czech Republic (Cited in Kim Bog-gi Archive).

\section{Conclusion: Reconsidering Pai Un-Soung}

For Pai, Europe was a land of liberty and opportunity. He realized the importance of understanding Asian classics, rather than just striving after knowledge about Western paintings. Furthermore, he endeavored to see cultural and artistic differences between the East and the West and to harmonize them through his art. Europe was the very place for him to establish his artistic identity of "Koreanness," and his art philosophy of "Eastern Lines and Western Colors." Not only that, Pai had many chances to take an active part on the international stage. Many artists and social forces with whom Pai formed a relationship, including the capital raised by Japanese powers, made it possible for him to work in various fields of activity all over Europe. This was an extraordinary achievement for Korean art, and its involvement in global activity.

There is a limit in his activities as well. While his "Eastern Lines and Western Colors" art was highly valued and favorably reviewed by Europeans as exotic and unique, it was criticized as 'materialist art 素材主義' in Korea.[23]

37 Frank Hoffmann, ibid, p. 96; An Asian of Calm and Versatile Talents: Interview with Kurt Runge, Monthly Art, Seoul, Monthly Art, 1991.4. pp. 64-65. 
Koreans believed that Pai took advantage of his popularity with his paintings, which were thought to pander to the exoticism of Europeans. He was also thought to have merely consumed Korean images and relegated the cherished traditions of Korea. It was the same for his relationship with Japan. As already mentioned, Pai had received considerable help from the Japanese and had participated in activities related to Japan. This relationship may have been continued after Pai's returning to Korea. The problem was that Japan had plunged into the war by that time and Pai was obliged to cooperate with them. Because of this, he was finally branded as an anti-nationalist or pro-Japanese collaborator after the liberation of Korea.

The only thing Pai really wanted may have been a life as a modern artist who dedicates himself to art. He strongly insisted that the "artist must live just as an artist," and he also said that the "artist's work is a sincere one, therefore the artist must refrain from being politically rampant."[24] $\mathrm{He}$ never wanted to be swayed or agitated by any political ideology and wanted just to be absorbed in art. In this sense, he ultimately hoped to settle in Paris. ${ }^{38}$ Nevertheless, he could not go back to Paris again, but instead defected to North Korea after the Korean War and ended his life there at the age of 78 .
American socialist Robert Ezra Park says in his marginal man theory that:

(Marginal man indicates) the man on the margin of two cultures and two societies, which never completely interpenetrated and fused [...] whose mind is divided and who tends to show the spiritual instability, intensified self-consciousness, restlessness, and malaise.[25]

Pai's life in Europe seemed to have been the life of a marginal man. His art still seems to wander to the boundaries of tradition and modernity, the East and the West, and the internationalization of Korean art and its acceptance by Western art. The reason Pai's life in Europe is noteworthy is not only because of his accomplishments there. The true reason his European experience is important is that we can understand the social and cultural conditions both of Europe and Asia, and thereby understand the artists' precarious life in that era. The rise and fall of Korean modern history is projected upon his body of work. 


\section{Appendix}

Table 1. Pai Un-soung's activities in Europe

\begin{tabular}{|c|c|}
\hline 1900 & Born in Seoul. \\
\hline 1922 & Moved to Berlin (via Marseille, France). \\
\hline 1925 & $\begin{array}{l}\text { Enrolled as a regular student in the Unified State Schools for Fine and Applied Arts. } \\
\text { Taught by a German folkloric-styled painter whose name was Ferdinand Spiegel . }\end{array}$ \\
\hline 1927 & $\begin{array}{l}\text { Awarded a third prize in the student art contest of the Unified State Schools for Fine and Applied Arts. } \\
\text { - Woodcut Self-Portrait was selected for Autumn Fair. }\end{array}$ \\
\hline 1929 & $\begin{array}{l}\text { Submitted five pieces of his woodcut including Drinking Outdoors, Mother's Affections to the International Art Fair. } \\
\text { Drinking Outdoors was Published in the French weekly newspaper Illustration }\end{array}$ \\
\hline 1930 & $\begin{array}{l}\text { - Graduated from a research course of the Unified State Schools for Fine and Applied Arts. } \\
\text { Held the first solo exhibition at the Fritz Gurlitt Gallery in Berlin: Exhibited } 40 \text { pieces oil paintings, woodcuts and watercolors. } \\
\text { Became a member of the department of Cultural Center in Germany. }\end{array}$ \\
\hline 1931-32 & $\begin{array}{l}\text { Held solo exhibition for woodcuts in Warsaw, Poland. } \\
\text { Held solo exhibition for watercolors at the Hague Municipal Fine Art Association, the Netherlands. } \\
\text {. Held solo exhibition at the Vienna Municipal Art Association, Austria. }\end{array}$ \\
\hline 1933 & - Submitted Drinking Outside, Brief Repose, Fantasmagoria World etc. to the International Exhibition of Woodcuts in Warsaw. \\
\hline 1935 & $\begin{array}{l}\text { - Held solo exhibition at the Fritz Gurlitt Gallery in Berlin. } \\
\text { · Held solo exhibition at Museum of Ethnology, Hamburg: Exhibited } 87 \text { paintings including Family Portrait, Korean Child, and } \\
\text { Baron Mitsui and His Works. }\end{array}$ \\
\hline 1936 & $\begin{array}{l}\text { - Held solo exhibition in Prague, the Czech Republic: Exhibited } 100 \text { pieces of artworks. } \\
\text { - Woodcuts including Baron Mitsui and His Works was selected for the second International Exposition of Woodcuts held in } \\
\text { Warsaw, Poland and awarded honors. }\end{array}$ \\
\hline 1937 & $\begin{array}{l}\text { - Got married Madlonka Baroness von Wrede. } \\
\cdot \text { Left for Paris. (September) }\end{array}$ \\
\hline 1938 & $\begin{array}{l}\text { - Submitted Portrait, Winter Landscape, Child, Flower and Returning Home to the Salon: Became the member of department of } \\
\text { decorative art. } \\
\text { - Held solo exhibition at the Charpentier Gallery: Exhibited } 38 \text { oil paintings, } 24 \text { watercolors and woodcuts. } \\
\text { - Returning Home, Korean Child and Baron Mitsui and His Works were selected for the Autumn Fair. } \\
\text { - Submitted World Tour to the Japanese Artists' Exhibition in Paris. } \\
\text { - Produced illustrations for the France-Japan (March, April and June issues). }\end{array}$ \\
\hline 1939 & $\begin{array}{l}\text { - Produced illustrations for the France-Japan (January issue). } \\
\text { - Submitted Children's Game and Portrait of author to the Salon. } \\
\text { - Submitted Voltre for the Japanese Artists' Exhibition in Paris. }\end{array}$ \\
\hline 1940 & Returned to Korea. (June) \\
\hline
\end{tabular}

Table 2. Pai Un-soung's paintings owned by European museums

\begin{tabular}{|c|c|c|}
\hline CITY, COUNTRY & MUSEUM & TITLE \\
\hline Berlin, Germany & Ethnological Museum & $\begin{array}{c}\text { Self-Portrait in Shaman-costume, } \\
\text { Children Spinning a Top }\end{array}$ \\
\hline Hamburg, Germany & Museum of Ethnology & Baron Mitsui and His Works \\
\hline $\begin{array}{c}\text { Prague, } \\
\text { the Czech Republic }\end{array}$ & The National Gallery in Prague \\
$\begin{array}{c}\text { Rohozec, } \\
\text { the Czech Republic }\end{array}$ & Hrubý Rohozec Castle & World Tour \\
\hline
\end{tabular}

Table 3. Articles and Illustrations of Pai Un-soung in France-Japan

\begin{tabular}{|c|c|c|c|c|}
\hline \multirow{2}{*}{ DATE } & ISSUE & TYPE & TITLE & PAGES \\
\hline \multirow{2}{*}{19383.15} & \multirow{2}{*}{27} & Illustration & Child of Korea & 119 \\
\cline { 3 - 5 } & \multirow{2}{*}{1938.4 .15} & Article & Exotic Artists in Paris: Korean Artists Un-Soung PAI & $118-119$ \\
\cline { 3 - 5 } & \multirow{2}{*}{1938.6 .15} & Illustration & Tille Page & 195 \\
\hline \multirow{2}{*}{1938.11 .15} & 30 & Article & Game of Korean Children & 274 \\
\hline 1938.12 .15 & 36 & Allustration & Taek-Won CHO, dancing a Buddhist dance & 513 \\
\hline 1939.1 .15 & 37 & Article & Automn Fair: & 566 \\
\hline
\end{tabular}




\section{REFERENCES}

[1] Herbert Blanken, Ein Kunstler des Fernen Ostens: Der Koreaner Maler Unsoung Pai, Illustrirte Zeitung, Leipig, Bd.187, Nr.4779, p. 502, October 15, 1936.

[2] Our great maestro who is winning his fame in the world: $\mathrm{Mr}$ Pai Un-Soung, Dong-A Daily News, January 8, 1939.

[3] Yasumatsu Miyuki, Japanese art in "East Asian" Art: Activities of modern German "Society for East Asian Art", Inaga Shigemi ed., Oriental Consciousness Between Fantasy and Reality: 1887-1953, Tokyo, Minerva Shobo, pp. 247-250, 2012.

[4] Kristian Bahnson, 'Über ethnographische Museen' Mitteilungen der Anthropologischen Gesellschaft, vol.18, p.114. [Cited in Korea Rediscovered! Treasures from German Museums, Seoul, Korea Foundation, p. 12, 2011].

[5] Yun Beom-Mo, Pai Un-Soung, His local color or exoticism spread out in Europe under the Japanese rule, Pai Un-Soung, Catalogue of Exhibition, Seoul, National Museum of Modern and Contemporary Art, 21p., 2001.

[6] Frank Hoffmann, Berlin Koreans and Pictured Koreans, Wien, praesens, p. 92, 2015.

[7] M.R.K. Ein Koreanischer Kunstler in Deutschland, Hamburger Fremdenblatt, Nr.81, Marz 22, 1935.

[8] Talk/Dialogue: Report of the two who have returned to korea lately from war-torn Berlin, Paris, and Belgium, Samcheolli, p.110, Dec. 1940 .

[9] Choi Gwang-Jin, Aesthetics of Korea: Discussing the differences between those and China or Japan, Gyeonggi-Do, Art Culture, pp. 98-139, 2015.

[10] Visiting atelier of Un-Soung Pai, Chunchu (Spring and Autumn, 春秋'), Seoul, Chunchusa, pp. 90-91, June 1943.

[11] Frank Hoffmann, Berlin Koreans and Pictured Koreans, Wien, praesens, p. 92, 2015.
[12] Yanagi Muneyoshi, Chosun and its art; in vol.4 of the Complete Works of Yanagi Muneyoshi (Yanagi Muneyoshi Zenshü), Tokyo, Shunshusya, pp. 109-122, 1972.

[13] Hong Sa-Joong, Eyes Beholding the Beauty: Rediscovery of the Aesthetics of Korean, Seoul, Art Books, p.127, 2006.

[14] Assian Rubinstein, Unsoung Pai, Beaux-Arts, Le Journal des Arts, n.284, June 10, p.4, 1938.

[15] Chung Hyung-Min, The Concept of the 'Orient' and Modern Korean Art, Seoul, Seoul National University Press, p.88, 2011.

[16] Long-awaited international "Olympics" is near at hand: Introduction of news team for this paper, Dong-A Daily News, July 27, p.2. 1936.

[17] Susanne Knödel mit Katharina Kosikowski, Uta Werlich eds., The Korean Collection of the Museum of Ethnology Hamburg, Korea Rediscovered! Treasures from German Museums, Seoul, Korea Foundation, pp. 96-97, 2011.

[18] Yokoyama Kaname, Chronology of Mitsui Takaharu, Hokkaido, Yokoyama Kaname (not for sale), 1984.

[19] U.T., Unsoung Pai, Hamburger Anzeiger, Nr.69, Marz 22, 1935.

[20] The First Japanese Artists' Exhibition in Paris, Binokuni (Country of Beauty) vol.15. Issue 3, Binokunisya, p. 55, March 1939.

[21] Japanese Artists' Exhibition in Paris, France-Japan, vol.37, p.53, January 15, 1939.

[22] Japanese Artists in Paris and Their Works, Le Petit Parisien, 1938.12.29; The Second Japanese Artists' Exhibition in Paris, Binokuni (Country of Beauty) vol.15. Issue8, Binokunisya, pp. 28, August 1, 1939.

[23] Park Go-Seok, Authenticity of Oil Painting: Pai Un-Soung's Art, Kyunghyang Shinmun (Daily News), 29, December, 1948.

[24] Dialogue/symposium on paper: Culture growing with National Foundation, Kyunghyang Daily News, Aug. 15, 1948.

[25] Park, Robert Ezra. Human migration and the marginal man, American Journal of Sociology, Vol.33 (6), pp. 892-893, May $1,1928$. 